Review

\title{
A Political, Economic, Social, Technology, Legal and Environmental (PESTLE) Approach for Risk Identification of the Tidal Industry in the United Kingdom
}

\author{
Athanasios Kolios * and George Read \\ Department of Offshore, Process and Energy Engineering, School of Engineering, Cranfield University, \\ Cranfield, Bedfordshire MK43 0AL, UK \\ * Author to whom the correspondence should be addressed; E-Mail: a.kolios@cranfield.ac.uk; \\ Tel.: +44-1234-754631.
}

Received: 8 July 2013; in revised form: 14 August 2013 / Accepted: 4 September 2013 /

Published: 27 September 2013

\begin{abstract}
This paper presents a comprehensive analysis of renewable and especially tidal energy through a political, economic, social, technology, legal and environmental (PESTLE) analysis approach and by reviewing the most up to date relevant literature. The study focuses on the United Kingdom given the favourable environmental resources for such technologies; the number of different design concepts that are currently under development as well as the research funding that has been invested over the last few years. Findings of the analysis identify the risks and multiple stakeholders involved at all stages of the tidal energy projects development from the conceptualization of the design, right through to decommissioning. Many of the stakeholders present benefits to the tidal developers through funding, incentives and knowledge sharing, but at the same time they also present potential risks to the future of projects. This is mostly down to different approaches of the most important aspect of tidal energy that needs to be considered, making it hard for technologists and developers to equally address all requirements. From this research it can be concluded that several of these risks can be mitigated early on providing that particular stakeholders are involved at the correct stage of a project.
\end{abstract}

Keywords: PESTLE analysis; tidal industry; risk identification 


\section{Introduction}

The marine energy industry has been forecast to be worth $£ 6.1$ billion to the UK economy by 2035 , creating nearly 20,000 jobs in the process [1]. The industry is made up of offshore wind, wave energy and tidal stream energy, with tidal energy having particular scope for growth within the UK having "around 50 per cent of Europe's tidal energy resource" [2]. The UK has recently been described as "the undisputed global leader in marine energy" with it currently having more wave and tidal stream devices installed than the rest of the world combined [3].

The growth of the UK marine energy industry so far has been helped by numerous government funding support schemes such as the Renewables Obligations Order which is "the main support mechanism" for renewable electricity projects within the UK, with smaller scale generation being supported through Feed in Tariffs [4]. Along with this continuous incentive for electricity production there have also been numerous sources of funding provided by various government and private sources such as the Department of Energy \& Climate Change (DECC) innovation funding for low carbon technologies [5]. The Crown Estates have also pledged their support by leasing out 37 tidal and wave sites around the UK between 2010 and 2013, believed to be more than any other country, to help "build and maintain a global lead" in wave and tidal energy [6]. There are also a number of other projects which the Crown Estates are willing to cooperate with and eventually aim grant to leases in the future.

Tidal energy power is still in relatively early stages of development in comparison to other forms of renewables such as wind power and in order for the industry to be a success, potential investors must be continually attracted in order to secure the vital funding [7]. To secure the required funding all of the potential risks faced by the industry must be identified in order to allow the optimum utilization of resources. This study employs a political, economic, social, technology, legal and environmental (PESTLE) approach to ensure that all involved disciplines are covered, as well as identifying the key stakeholders involved in marine and specifically tidal energy. For this to be achieved, the most up-to-date literature, reports and guidelines are included in the sections to follow.

\section{Contribution of Tidal Technologies to Renewable Energy Targets}

Renewables' share of electricity generation in the UK was a record 11.3 per cent in 2012, increasing 2 percentage points from the previous year [8], with the trends expected to carry on increasing in order to achieve the EU directive of 20\% renewable energy by 2020 [9]. The current installed capacity of tidal energy is almost $9 \mathrm{MW}$ [3] with theoretical UK resources of tidal stream energy predicted to total $32 \mathrm{GW}$ [10], implying that the $20 \%$ renewables obligations could be fulfilled by this form of energy alone [11]. A study by the Met Office [12] revealed the potential sites for in-stream tidal energy devices to be located with Scotland alone having $25 \%$ of Europe's tidal energy resource around its coastline [13].

In order to achieve these targets and make use of the resources the UK has in its waters, previous scientific knowledge must be applied. As tidal energy is still a juvenile industry there are gaps in data regarding various aspects of a political, economic, social, technologic, legal and environmental (PESTLE) analysis, therefore experience of other types of similar projects must be used. For example knowledge can be transferred from the wind industry to identify economic issues and knowledge of 
offshore structures can be used to predict technological risks including failure rates and design requirements (i.e., fatigue life) of key components. This knowledge can only be transferred to a certain extent as new challenges arise specific to in-stream tidal devices that have not been truly uncovered yet such as the effects on the environment and navigational issues created by positioning large devices out of sight. There is also a large amount of confusion surrounding the legal framework of tidal energy, with ineffective practices regarding previous energy policy trying to be avoided in order to facilitate growth of the industry. The social effect of such devices is also not yet fully understood as it may not have the same "Not in my back yard" (NIMBY) effect as wind farms have had due to tidal devices being out of site. NIMBY is a characterisation of the local population who oppose developments due to them happening in proximity to their locations of interest.

\section{PESTLE Analysis}

\subsection{Political}

Politics has the potential to have a dramatic effect on the future of tidal energy presenting many opportunities alongside many risks to existing and future tidal developments. The UK government alone does not have complete control as its policies are dictated to an extent by World and European level politics.

The United Nations [14] have a number of advisory boards in order to provide "sustainable energy for all" with the primary focus being on providing energy for all to access, but at the same time promoting sustainable energy sources such as renewables with particular emphasis being placed on the environment impact. The United Nations Conference on Sustainable Development (Rio+20) [15] summit was a meeting of global leaders, experts, private sector participants along with many others in order to pledge $\$ 513$ billion to fund future developments, whilst at the same time creating more political pressure to achieve the stability of the world's energy. The United Nations Development Programme [16] is also in place alongside the Rio+20 project in order to support "sustainable, low carbon, climate resilient development pathways". Other organisations providing political influence on a world level include the International Energy Association (IEA) and the International Renewable Energy Agency (IRENA) [17] which are both intergovernmental agencies focusing on "supporting countries to a sustainable energy future".

The European Commission [18] has set a target for countries within the EU by 2020 to achieve a 20\% reduction in EU greenhouse gas levels from 1990. Alongside the European Commission are the Agency for the Cooperation of Energy Regulators [19] who "work towards a single European Market". These two political bodies are currently applying significant amounts of pressure to member states in order to secure a sustainable energy future. But perhaps the most applicable European level agency is the European Ocean Energy Association [20] which gives advice and applies pressure to the member states. The main risk associated with European level politics is that relevant stakeholders may identify already proven technology as the future, rather than focusing on new emerging technologies such as tidal energy.

All of the international agencies intend to provide stability for the future of renewable energy by providing funding, setting policy requirements and sharing knowledge whilst at the same time having the environment high on their agendas. The most significant political risks come at national level, 
mostly due to the fact that each party is in power for a relatively short fixed term focusing on their own separate agendas. This coupled with the fact that world economic crisis of the last 6 years has led to government cut backs in spending, may see renewables losing vital funding. DECC [21] have recently agreed with HM Treasury to cut its budget by $10 \%$ in order to reduce government spending.

The current coalition government in the UK previously stated in their agenda that they intended to support an increase in carbon reductions to $30 \%$, exceeding renewables [22]. The plan is well documented in the Renewable Energy Roadmap [23] and in the update of this edition in December 2012 it states that "the UK is still on track to meet the first interim results" by increasing renewables contributions to $3.8 \%$ of the total energy production of the UK. Examples of other party's policies include the Labour policy [24] wanting to make the UK the "world leader" in tidal energy, with the UK Independence party's policies being described as "a mixture of anti-environmentalism and a disregard for scientific evidence" [25].

Internal politics within the UK is also not uniform throughout with the individual regional governments for England, Scotland, Wales and Northern Ireland developing their own policies. England follows that of the coalition government set by DECC. The Welsh Assembly Government [26] has visions of making Wales the "world-leader in the marine energy market" through Sustainable Expansion of the Coastal and Marine Sectors (SEACAMS) and Low Carbon Research Institute (LCRI). The Scottish Government [27] is committed to providing " $100 \%$ of its electricity demand from renewables" with significant funding being put in place for further projects as it plans to use its $25 \%$ share of Europe's tidal stream power. Finally Northern Irelands marine energy is currently governed by the Department of Trade, Enterprise and Investment Northern Ireland which also follows the policies provided by DECC.

The future of international marine energy from a political point of view is relatively secure in that most nations have pledged long term agreements to reduce carbon emissions and increase the contribution of renewable energy to the nation's energy mix. However, politics do have the ability to have negative effects on the future of tidal energy with this risk coming internally within a nation due to the competing interests of governmental parties on an ever increasingly tight budget.

\subsection{Economical}

There are numerous economic factors that must be considered for the tidal energy industry. The most noticeable is perhaps funding as this was identified in a report of stakeholders as "the biggest hurdle" to tidal energy and that it is the key to any future developments [28]. In order to understand the true costs associated with developing tidal energy a report was published by Ernst and Young [29] which presents a breakdown in estimated cost for tidal stream projects in the UK. It was found that base costs at a medium resource were $£ 2.7$ million in capital expenditure per megawatt and $£ 0.03$ million per megawatt per year in operating expenditure over the projects expected service life. These seemingly high costs are due to the technology being in there early stages of development. Another report [30] outlined that the industry is too fragmented (too many different design configurations exist) and that the market opportunities do not match investment timescales. From carrying out stakeholder interviews they noted that in order for investment to come in from the private sector, public sector investment must be pledged first. The unwillingness to invest so eagerly may also 
be down to the effects of the global recession as suggested by the Low Carbon Economy [31]. The future of the World and UK economy still appears uncertain, which poses further risk to the future of tidal energy developments.

On a European level there is support through the European Commission and Community Research and Development Information Service (CORDIS) [32], with the majority of their investment being handed out through national governmental departments. Within the UK, DECC [5] provides funding for England and Wales in funding for low carbon technologies with an example being the $£ 20$ million Marine Energy Array Demonstrator scheme (MEAD) as part of DECCs $£ 200$ million budget for low carbon technologies for 2010-2015 [33]. The Carbon Trust [34] provide grants such as the Marine Renewables Proving Fund worth up to $£ 22.5$ million in total with an average grant of $£ 3$ million, as well as the Marine Renewables Commercialisation fund for Scotland [35]. The Energy Technologies Institute is a public-private organisation providing investment for marine energy projects in order to achieve the UKs renewables aims [36]. From 2008 to 2012 they invested $£ 24$ million in marine energy with future funding yet to be announced [37]. The Technology Strategy Board [38] also provides funding through competitions such as the Knowledge Transfer Partnerships in which £1.2 million was invested. Their total spending from 2007 to 2011 was $£ 22$ million for R\&D on wave and tidal energy [39]. Scotland has its own exclusive funding such as the $£ 13$ million Scottish Ministers Wave and Tidal Energy Support Scheme [40] and the $£ 10$ million Saltire Prize [41]. Finally, Northern Ireland receives UK funding as well as its own specific funding from Department of Enterprise, Trade \& Investment Northern Ireland [42] as part of their Renewable Energy Action Plan. With the EU and the UK government already committed to provide funding to the renewable energy sector, it is expected that their inputs will attract the crucial private sector investment to make tidal energy commercial.

In order for the technology to become part of the UK energy market the cost of production must come down. The Carbon Trust [11] put the cost of producing tidal energy at around $30 \mathrm{p} / \mathrm{kWh}$ with it expected to drop to around $16 \mathrm{p} / \mathrm{kWh}$ by 2020 , with others predicting a faster increase in price reduction which is needed for the technology to become competitive. These prices do not just need to be competitive to other forms of renewables but also with conventional sources of power production. If they do not come down in price quickly enough, there is the risk that other forms of renewable energy will become accepted and further commercialised and tidal energy will be neglected.

The UK government have the Renewables Obligations Order and Feed in Tariffs (for smaller investments) in place to offset the extra costs of renewable energy in the lower scale production [43], however developers cannot rely on this completely as prices have fluctuated in the last few years. The government does however plan to fix these costs by 2027 in order to decrease risk for developers [43]. The government is also showing their intentions by increasing the level of Renewable Obligation Certificates (ROCs) from 0.158 ROCs per MWh last year, to 0.206 ROCs per MWh for all energy supplied to customers in England and Wales. ROCs are "green certificates issued by the authority to operators of accredited renewable generating stations for the eligible renewable electricity they generate" [4]. This number is expected to increase gradually each year, increasing the support of renewables at the same time as suppliers will have to either invest directly in renewables to present ROCs to Ofgem (regulators of the electricity and gas market in the UK), or by making a buyout payment to Ofgem which will then be invested back into the suppliers who meet there ROC quota. 
If the conditions of the UK energy market were to stay the same, marine energy could be making a positive contribution within the next few years but there is the possibility of conditions changing. A report by Henriques and Sadorsky [44] highlights the effects of oil prices on the renewable energy market and that increasing prices of oil will lead to higher interest in renewables. The shale gas revolution has the potential to affect renewables even more, with Massachusetts Institute of Technology (MIT) [45] and National Geographic [46] both claiming that it will "stunt" the growth of the industry.

Providing the marine energy industry continues to grow it will have the potential to "generate high returns when it comes to jobs particularly when projects are located in remote areas" [47] due to its "labour intensity", creating more jobs per pound invested than conventional electricity generation technology [48]. But as the development of tidal energy is still in such early stages it is still very high risk not only for investors, but also for insurers hence the "limited numbers" of insurers currently operating in the market [49]. Insurance is more likely to be given if insurers and certification authorities are involved early on in the design process.

Banks have the potential to provide finance for the tidal energy sector but according to a report by Vivid Economics [50] banks have been restricted on the lending they can provide due to the world economic crisis and that "lenders are becoming increasingly selective and are scrutinizing investment opportunities much more vigorously". Banks are increasingly likely to turn down long term investment opportunities due to its high cost and instead focus on more short term lower risk projects [51]. The Green Investment Bank was set up in 2012 to accelerate the UKs transition to a more green economy by providing $£ 3$ billion to green projects.

\subsection{Social}

Social aspects of technology are often overlooked by developers at early stages, potentially being a costly mistake for tidal developers as this group of stakeholders have in several cases delayed and even stopped projects completely. This potential for socially inspired delay can be exemplified by groups in Powys, where Britain's biggest ever public enquiry is taking place over the deployment of 500 MW's worth capacity of wind turbines [52]. The enquiry began on the 4 June 2013 and is expected to conclude in the spring of 2014 with the council earmarking $£ 3$ million in funding [53]. This public enquiry was carried out after thousands of signatures were gathered opposing the developments as they would damage the natural beauty of the surrounding area. This highlights the idea that in principle the public accept renewable energy, but with opposition to individual projects on a more local level remaining frequent [54] especially with regards to "not in my back yard" syndrome" [55]. However Devine-Wright [56] argues that it isn't just a case of NIMBY but is more that people get attached to the surroundings of where they live and that they don't like any "change", whilst citing that "nature is unspoilt at this place" as a lot of the best renewable resources are located in remote places.

In-stream tidal energy is significantly different to wind energy in that it is positioned below the surface of the water and it was also found that only 55\% of people in the UK are actually aware of tidal power [57], with many knowing only of tidal barrages and hydro power and not in-stream devices. However, it has been a number of years since the report, with in-stream tidal energy gaining more publicity. Social acceptance of clean energy seems to be the main theme of many reports such as that 
by Pidgeon et al. [58] where it is argued that people should make the decision between climate change or a change in the way we live. Batel et al. [59] take it a step further and that it is not just a case of the population accepting renewables, but also that they actually must support the technologies in order for major progress to continue. Howell and Drake [60] report that if the tidal developers and the local communities work together with information being exchanged readily, the support can be far greater and that there actually forms a sense of "pride and excitement" in the local community [61]. This is provided that they first get over the concerns about negative local outcomes of the developments.

As well as giving consideration to the general public and to local communities as a whole, there are specific stakeholder groups who have an active involvement with marine energy developments. There are the local fishing communities that must be considered with Mackinson et al. [62] revealing that no concern is given to them at an early enough stage in marine energy development and that if they were informed early enough, they would be able to plan future fishing better. Again this highlights the communication issues within the industry and its external stakeholders. It was also noted that there must be mitigation options in place to fleets that may be disadvantaged such as incentive schemes and causing minimal environmental impacts that could affect fish levels. Dredging must also be considered in the same way that fishing is.

Marine energy developers, and in particular tidal energy developers, must work closely with commercial shipping and recreational boating [63] to primarily avoid accidents through collision if placed too near shipping lanes or in busy sailing areas. The Royal Yacht Association [64] outlined a number of key points that developers must follow in order to mitigate the risk of recreational boating disrupting tidal projects (with the same rules being applicable to commercial shipping). These include; creating a minimum underwater clearance of $8 \mathrm{~m}$ below chart datum, correct marking and lighting, minimising effects on navigation and communication equipment and avoiding busy and popular routes. The Maritime and Coastguard Agency [65] offers guidance to mariners operating nearby to offshore energy installations with focus also given to the emergency services.

One final social group of stakeholders that must be considered are tourists. Reports so far suggest that offshore installations have attracted tourists especially when nearby information centres are developed [66]. However this increase in tourism may not be sustained in the future, as people may start to resent the technology as it becomes more common which may impact local communities so impact to tourism should be concluded neutral.

\subsection{Technological}

The ability to harness some of the world's most abundant tidal energy presents the UK with a piece of technology that could have a significant impact on the country's overall energy generation [67]. The developer with the highest output power and efficiency rating may be seen as the most attractive to potential investors, but with the technology behind tidal energy still in its early stages there is still great risk in the development stage, with this being one of the main reasons why banks have not yet invested in the technology [1].

In order to produce ground breaking new technology it is essential to distinguish and develop required expertise, as well as identify a supply chain that is capable of producing components and systems. Scottish Enterprise [68] has created an online portal so that developers can easily identify 
their supply chain. It is common practice to over engineer the designs which may in turn make them less cost effective to commercialise, therefore thorough techno-economic analysis must also be carried out in order to reduce this risk [69]. A way of conducting this analysis could be through learning from outcomes of other industries such as onshore and offshore wind. It is also important that developers put significant effort into achieving reliability and availability thresholds considering the harshness of the environment and the restrictions in interventions [70].

Despite some of the oldest ocean energy technologies having used tidal power in the past in the form of barrages or dams [71], no one design has yet been accepted as the norm as yet for in stream-tidal turbines, unlike in wind energy where turbines are mostly two or three bladed on a steel or concrete tower. The European Marine Energy Centre (EMEC) [72] identifies six main types on in stream tidal devices; horizontal axis, vertical axis, oscillating hydrofoil, enclosed tips, Archimedes screw and tidal kites. They also claim there are still a number of devices being worked on that cannot be grouped into one of the six sections due to their "unique" design. There are also a number of different fixing methods including; gravity base, flexible mooring, rigid mooring, pile mounted, hydrofoil inducing down-force, attached to floating structure and fixed [73]. A thesis by Seibert [74] and a report by BMT Cordah [75] explore the different anchoring and mooring systems available in a cost effective way. These studies were carried out as there are high costs associated with mooring whilst at the same time the footprint needs to be kept as small as possible The plethora of designs under development (in different stages of maturity) means that it is very competitive in terms of producing the best design in order to win over investors, therefore it is important that developers produce a truly world class design and are committed throughout the project.

Lessons from wind turbines in terms of reliability should be taken into account when assessing tidal turbines and as tidal energy has a much higher power density than wind [76]. This higher power density means that higher amounts of energy can be produced for the same swept area, but that will also lead to a dramatic increase in loading along with the cyclic loading caused by waves. A report by Department of Trade and Industry (DTI) [77] highlighted that there was scope for error in the following areas of an in-stream tidal device; rotor, power train, electronics, control systems, communications, structure, cabling, foundations, anchoring, mooring, access and servicing. The likelihood of failure increases as the depth of the sea increases and with $90 \%$ of the extractable energy in the top $10 \mathrm{UK}$ mainland sites lying in waters $40 \mathrm{~m}$ or more in depth, the design process must be even more vigorous [78]. A key challenge here is the different behaviour of components that have not been designed for subsea application.

Industry standards recommend using failure mode and identification planning in order to mitigate the risks of failure such as the Structured What-if-Technique (SWIFT), Hazard and Operability Study (HAZOP), Fault Tree Analysis (FTA) and Failure Mode and Effect Analysis (FMECA) [79]. As well as using theoretical modelling, computer aided engineering has become a vital part of testing devices. Research organisations such as the National Renewable Energy Laboratory (NREL) [80] are currently collaborating with national laboratories, agencies, universities and industry to develop validated computer simulations which can be used to improve the performance of hydrokinetic energy converters. This technology is not just being used for single units, but for array scale farms as this is seen as the biggest area of technological uncertainty [81]. After theoretical and computer modelling is carried out the correct sequence of prototyping and scaling up. These stages are concept/tank testing, part scale 
demo, full scale at sea demo, first farm deployment and finally full commercial [82]. EMEC [83] offer draft standard for marine energy devices which help in all aspects of building an effective and reliable structure. These prototyping stages are vital in producing a reliable device and work should be done primarily at small scale before scaling up, as the financial risks are much lower at this point. Selecting the appropriate scale ratio for each stage is also vital, as the scaling effect applies between the tank test and real scale performance.

There are a number of key processes which present multiple risks once the design has been finalised including; installation, commissioning, grid connection, maintenance, removal and decommissioning. The Crown Estates [84] have issued guidelines for installation and maintenance procedures with relevant risk assessments for all stages along the way, with grid connection issues highlighted in a report by OffshoreGrid [85]. Both reports highlight the significant costs off installation. As decommissioning must be carried as a legal requirement it is just as important to be carried out safely and cost effectively. A report was written by Climate Change Capital [86] highlighting all issues associated with it being noted that the main risk associated with decommissioning is the lack of experience and knowledge to be able to predict the true costs associated with this stage of development. As costs associated with deploying a tidal energy device are so high, their lifecycles must be closely looked at in terms of payback period and carbon footprint [87].

\subsection{Legal}

Currently legislation and regulations governing marine and tidal energy devices are very complicated, with the Department of Environment, Food and Rural Affairs (DEFRA) [88] identifying the need to simplify them in order to reduce legislative risk for developers. Even if this simplification goes through there are still a number of legislative policies which apply to tidal energy devices within the UK and this section will look at these in more detail.

At world level there is the United Nations Convention on Law of the Sea which "lays down a comprehensive regime of law and order" which are applicable to all oceans and seas to establish rules to govern their uses [89]. This gives the sovereign state the control over water within 200 nautical miles of its coast amongst other rights. At a European level there are a number of directives which may be applicable to tidal energy including the Renewable Energy Directives in 2001 and the update in 2009 which make renewable targets legally binding for the countries who agree to participate [90]. If a participating country does not meet the targets they are liable to monetary penalties by the European Union such as those imposed on Poland and Cyprus in 2011 for not transposing the Renewable Energy Directive targets to their own nation. For Poland the Commission proposed a daily penalty of $€ 133,228$ and for Cyprus a daily penalty of $€ 11,404$ [91]. Strategic Environmental Assessments and Environmental Impact Assessments have become mandatory for tidal energy [92], these assessments look at both the positive and negative impacts a project may have on the environment and the measures taken to mitigate the impact. There are also the Habitats Directive [93] and the Wild Birds Directive [94] which both come under the Environmental Investigation Agency (EIA) directive and deal with the protection of species and their habitats. As well as these four main directives there is also legislation specific to the use of the marine environment in the form of The Water Framework Directive for improving the quality of water focusing on ecology [95] and the Marine Strategy Framework Directive to help 
protect the marine environment [96]. Finally in March 2013 the Marine Spatial Planning Directive was commissioned due to the high competition for maritime space [97].

Each member state is responsible for transposing the EU level legislation to their own legal system, giving great variance despite directive being in place [98]. This creates risk within the industry especially if developers are thinking of investing abroad.

From the guidelines provided in the EU directives the UK has moulded its energy policy and it is at this point where it becomes a risk for developers if they choose not to look into the legal framework in great detail. There is the Overarching National Policy Statement for Energy (EN-1) which outlines the planning procedures and consents for any energy development covering; the Planning Act 2008 and the Electricity Act 1989 [99]. There is also the National Policy Statement for Renewable Energy Infrastructure (EN-3) which covers planning processes for any renewable energy within England and Wales [100]. The planning process for England, Northern Ireland and Wales is carried out on behalf of DECC by the Marine Management Organisation which control licensing applications under the Marine and Coastal Access Act 2009 [101]. Even though Wales and N. Ireland work under the same act as in England, they have their own separate licensing teams in the form of the Marine Licensing Team for Wales [102] and the Marine Licensing team of the Department of the Environment Northern Ireland (DOENI) [103]. Scotland has its own licensing body in the form of Marine Licensing Scotland which acts under the Marine (Scotland) Act 2010 [104]. These policies create a framework in which planning must be consented before any development can get underway. Energy Infrastructure [105] has compiled a comprehensive list of recent decisions on applications within the UK. There are also strict laws regarding the decommissioning of structures also under the Energy Act 2004 [106].

Apart from just obtaining a license for placing a tidal energy device in the sea or ocean, access must be given by the Crown Estates in the form of a lease. In 2012 it was announced that the Crown Estates [107] had given leases to 36 wave and tidal developers. However these leases are not always granted and can therefore hinder the progress of a project. Along with this the correct health and safety procedures must be followed, with BWEA [108] and RenewableUK [109] providing guidelines in order to cover as many associated risks so that developers are not liable for any accidents at any stage of the project.

Finally with any new project and development there is always a risk that information may be disclosed to a competitor or that a patent may not be granted for a device. In order for information to stay safe, the correct procedures for any project with sensitive material should be followed [110].

\subsection{Environmental}

The UK government has committed itself to reaching EU targets on climate change and marine energy devices can contribute by producing energy with decreased greenhouse gas emissions, air pollution and damage from acid rain but only if managed correctly [111]. There is the possibility that developers may overlook other environmental impacts as they falsely assume that they are already contribute positively by saving on the use of fossil fuels. However, developers must consider the bigger picture and how their actions may have detrimental effects to the environment at any stage of the project. The environment in this context refers to the area surrounding the device and all that is contained within it. 
In order to help monitor the environmental uncertainty of marine energy devices two main directives were put in place by the European Commission; the Environmental Impact Assessment Directive and the Strategic Environmental Assessment Directive [92]. These were both put in place so that the environmental implications are considered before any decisions are made and they should be carried out for each individual project and device due to the "unique complex" of potential effects [112]. Public participation is a big part of these studies. There are a number of Environmental Impact Assessments (EIAs) and Strategic Environmental Assessments (SEAs) available in literature including the Sea Generation Environmental Monitoring Programme Report [113], Fundy Tidal Energy SEA [114] and a Study of the Strait of Messina [115].

Within the UK, DEFRA is the government department responsible for the policy and regulations on environmental issues, including those encountered by marine energy devices whilst helping to improve the economy [116]. In order to utilise a wider range of expertise DEFRA are supported by many public agencies to aid their work, with a number of them being heavily involved in marine renewables. The Joint Nature Conservation Committee (JNCC) provides advice to DEFRA and developers in the industry about nature conservation with regards to offshore renewable energy [117]. The Centre for Environment, Fisheries and Aquaculture Science (CEFAS) specialise in the management of the seas and oceans and pay particular attention to fish (farmed or wild). They help with policy and licensing and have published a number of reports including one on data acquisition to support marine renewable EIAs [118]. The Marine Management Organisation helps by providing licenses as part of the planning process for anyone wishing to "carry out an activity in the English or Welsh marine environment" whilst helping govern fisheries and marine planning [119]. There are also other specific groups to the countries within the UK that with marine energy developments whilst helping in the conservation of the environment; Natural England, Scottish Natural Heritage, Environments and Countryside Department (Welsh Assembly Government) and the Northern Ireland Environmental Agency.

Along with advisory agencies for the government, there are a number of charities aiming to protect the environment which could potentially form a barrier to the progress of tidal energy unless they are cooperated with. The World Wildlife Foundation [120] issued a report in which it declares that it will fully support marine renewables providing consideration was given to all mammals that could be affected. The Royal Society for the Protection of Birds (RSPB) fully support tidal energy devices as well, with it seen as an important contributor to carbon-free energy providing correct IEAs are carried out [121].

Despite there being numerous agencies working with tidal energy, there is a limited amount of data and information on the medium and long term effects of marine renewable energy devices [122]. Studies have been carried out in order to identify impacts which need to be investigated. These include; water circulation patterns, benthic habitats, artificial reef effect, water quality, sound disturbance, electromagnetic fields, avoidance behaviour, light disturbance and collision risk [123]. The UK also has important species of mammals and fish which have been specifically looked at such as; a report looking at effects on salmon [124], tidal energy effects on birds [121] and fish collision risk off the coast of Wales [125]. There is also the risk of damaging the man-made environment such as ship wrecks which are popular dive sites.

Many impacts have the potential to be high risk in terms of damage to the environment but with sufficient knowledge and the correct mitigation procedures, it is expected that all of the implications 
could have a low impact potential [126]. There have been numerous reports speculating what these implications could be, but until these devices have been deployed for a number of years it will be difficult to determine exactly the effects [127]. Linley et al. [128] also highlight the need for research in terms of scaling up a single device into a farm and the differences in environmental effects it will have then. There is also the uncertainty surrounding the decommissioning of devices and the environmental impact caused during this process. Finally the potential benefits must also be considered [129] such as the creation of safe zones out of the reach of fisherman.

\section{Discussion}

There are many risks and benefits associated with tidal energy, all of which may be considered most crucial to different stakeholders due to difference in focus, therefore making it difficult to pinpoint the overall most important factor which must be considered. Investors for example would see financing as the most critical risk in tidal energy development as they will want a return on their investment and will only invest if public money is committed at the same time. Whereas developers will primarily want their technology to be successful, but will always have techno-economic performance on their mind as the project will fall through without it. But then the general public may want social and environmental considerations as top priority due to the impacts it may cause on their everyday lives. The technological risks associated with tidal energy can be mitigated by following set design steps, using knowledge learnt from other industries and from extensive testing, deployment and monitoring.

There is a great number of stakeholders involved throughout a tidal energy project that makes it difficult to identify the requirements of them all hence the need for a framework in order to ultimately guide developers through the process of getting a tidal energy device to market. Each one of these stakeholders has the potential to delay or even stop a tidal development project if their requirements are not catered for which presents a major risk to technologists and developers. The legal framework regarding marine renewables is extensive in order to cater for the needs of all these stakeholders, highlighting the need for more simple legislation to be implemented towards a wider expansion of the industry.

It can also be noted from the findings of this analysis that there are several stakeholders having involvement in multiple areas of the PESTLE analysis which could dictate the future of the market on their own. The UK government is perhaps the biggest of these stakeholders with involvement in providing funding, licensing, the environment, policies and a social obligation to the general public. As long as they continue to commit to the marine energy sector, the short term future at least will have a positive outlook.

From this literature research it can be seen that the best way for developers to mitigate risk is by considering each development stage separately and considering all risks and stakeholders present at that stage. Once all risks at that particular stage have been mitigated to enough of an extent at that point, then the developers should move onto the next stage.

\section{Conclusions}

The UK has an abundance of marine energy sources in its coastal waters, which have the potential to play a major role in the future of the UKs energy mix. However with the industry still being in its 
early stages of development there are numerous areas of uncertainty which need to be explored to secure the future of the industry. To bridge these gaps in data this paper looks at the marine energy industry as a whole, and with a focus on tidal energy, identification of stakeholders was firstly carried out along with their associated benefits and risks which they may present to developers. This was done by carrying out a comprehensive PESTLE analysis, which is already accepted by industry as a comprehensive method of assessing the state of a particular industry or market.

The main focus of research in tidal energy so far has been predominantly based on engineering the technology. But for the technology to become viable on the market all other aspects of the PESTLE disciplines must be considered, as other factors have the ability to stop any developments before they can be deployed. So far many stakeholders were found to be supportive of tidal energy, but that they are weary of the technology as a whole due to it being relatively undeveloped. Research has also suggested that in order to mitigate many of the identified risks, stakeholders should be involved to share not just knowledge, but also differences in opinion. Working in this way could even turn risks into benefits, especially in regard to social and environmental factors. In identifying all stakeholders along with potential risks it is hoped that in turn a risk framework can be produced for tidal developers to follow to increase their likelihood of succeeding and making a positive impact on the future of low carbon energy.

\section{Acknowledgments}

This work was supported by the Natural Environment Research Council (NERC).

\section{Conflicts of Interest}

The authors declare no conflict of interest.

\section{References}

1. RenewableUK Web Page. Wave and Tidal Energy in the UK 2013: Conquering Challenges, Generating Growth. Available online: http:/www.renewableuk.com/en/publications/index.cfm/ wave-and-tidal-energy-in-the-uk-2013 (accessed on 7 June 2013).

2. GOV.UK Web Page. Wave and Tidal Energy: Part of the UK's Energy Mix - An Explanation of the Energy-Producing Potential of Wave and Tidal Stream Energy in the UK. Available online: https://www.gov.uk/wave-and-tidal-energy-part-of-the-uks-energy-mix (accessed on 7 June 2013).

3. RenewableUK Web Page. Wave and Tidal Energy - The Pull of Tides, and the Movement of Waves, Produces a Vast Amount of Power that Modern Technology is Harnessing. Available online: http://www.renewableuk.com/en/renewable-energy/wave-and-tidal/index.cfm (accessed on 9 June 2013).

4. Ofgem Web Page. Renewables Obligation. Available online: http://www.ofgem.gov.uk/ Sustainability/Environment/RenewablObl/Pages/RenewablObl.aspx (accessed on 9 June 2013). 
5. GOV.UK Web Page. Innovation Funding for Low-Carbon Technologies: Opportunities for Bidders-How to Enter Open Competitions or Bid for Upcoming Contracts in GovernmentFunded Low-Carbon Projects up to 2015. Available online: https:/www.gov.uk/innovationfunding-for-low-carbon-technologies-opportunities-for-bidders\#technology-innovation-needsassessments-tinas (accessed on 9 June 2013).

6. The Crown Estate Web Page. Wave \& Tidal Programme: Future Leasing-Industry Engagement Exercise. Available online: http://www.thecrownestate.co.uk/energy-infrastructure/wave-andtidal/publications/ (accessed on 7 June 2013).

7. European Marine Energy Centre Web Page. The Future of Marine Renewables in the UK; Eleventh Report of Session 2010-2012. Available online: http://www.emec.org.uk/marineenergy/industry-reports/ (accessed on 9 June 2013).

8. GOV.UK Web Page. Energy Trends Section 6: Renewables; Section 6 Covering Renewables Statistics of the Latest Edition of "Energy Trends" Publication. Available online: https://www.gov.uk/government/publications/renewables-section-6-energy-trends (accessed on 7 June 2013).

9. European Commission Web Page. The EU Climate and Energy Package. Available online: http://ec.europa.eu/clima/policies/package/index_en.htm (accessed on 8 June 2013).

10. The Crown Estate. UK Wave and Tidal Key Resource Areas Project; The Crown Estate: London, UK, 2012. Available online: http://www.thecrownestate.co.uk/media/355255/uk-wave-and-tidalkey-resource-areas-project.pdf (accessed on 7 June 2013).

11. Carbon Trust Web Page. Accelerating Marine Energy; The Potential for Cost Reduction - Insights from the Carbon Trust Marine Energy Accelerator. Available online: http://www.carbontrust.com/ resources/reports/technology/accelerating-marine-energy (accessed on 7 June 2013).

12. ABPmer Web Page. Atlas of UK Marine Renewable Energy Resources: Atlas Pages; A Strategic Environmental Assessment Report. Available online: http://www.renewables-atlas.info/ (accessed on 9 June 2013).

13. Scottish Development International Web Page. Wave and Tidal Energy in Scotland. Available online: http://www.sdi.co.uk/resources/brochures/energy/wave-and-tidal-energy.aspx (accessed on 7 June 2013).

14. United Nations Web Page. Sustainable Energy for All; Rio+20 the Future We Want. Available online: http://www.un.org/en/sustainablefuture/energy.shtml (accessed on 8 June 2013).

15. United Nations Web Page. What is "Rio+20"? Rio+20 the Future We Want. Available online: http://www.un.org/en/sustainablefuture/about.shtml (accessed on 8 June 2013).

16. United Nations Development Programme Web Page. Our Goals. Environment and Energy. Available online: http:/www.undp.org/content/undp/en/home/ourwork/environmentandenergy/ overview.html (accessed on 8 June 2013).

17. International Renewable Energy Agency Web Page. About IRENA. Available online: http://www.irena.org/Menu/index.aspx?PriMenuID=13\&mnu=Pri (accessed on 8 June 2013).

18. European Commission Web Page. Renewable Energy-Targets by 2020. Available online: http://ec.europa.eu/energy/renewables/targets_en.htm (accessed on 9 June 2013).

19. Agency for the Cooperation of Energy Regulators Web Page. The Agency. Available online: http://www.acer.europa.eu/The_agency/Pages/default.aspx (accessed on 8 June 2013). 
20. European Ocean Energy Association Web Page. About EU-OEA. Available online: http://www.eu-oea.com/about-us/ (accessed on 8 June 2013).

21. Combined Heat and Power Association Web Page. DECC Agrees Budget Cut with Treasury. Available online: http://www.chpa.co.uk/decc-agrees-budget-cut-with-treasury_1430.html (accessed on 28 June 2013).

22. The Coalition: Our Programme for Government. Available online: https://www.gov.uk/ government/publications/the-coalition-documentation (accessed on 8 June 2013).

23. Department of Energy \& Climate Change. UK Renewable Energy Roadmap Update 2012; Department of Energy \& Climate Change: London, UK, 2012. Available online: https://www.gov.uk/government/uploads/system/uploads/attachment_data/file/80246/11-02-13_ UK_Renewable_Energy_Roadmap_Update_FINAL_DRAFT.pdf (accessed on 8 June 2013).

24. The Labour Party Web Page. A Greener Britain; Building a Low Carbon Society Presents Opportunities as well as Challenges. Available online: http://www.labour.org.uk/ vote2009_greener (accessed on 8 June 2013).

25. The Guardian Web Page. UKIP's Energy and Climate Policies under the Spotlight; Environment Blog. Available online: http://www.guardian.co.uk/environment/blog/2013/mar/04/ukip-energyclimate-policies (accessed on 8 June 2013).

26. Welsh Government Web Page. Marine Energy; Wales Has the Potential to Be a World Leader in the Marine Energy Market. Available online: http://wales.gov.uk/topics/environmentcountryside/ energy/renewable/marine/;jsessionid=5B554FD50D1D85FD06D576FEE2660F98?lang=en (accessed on 8 June 2013).

27. Scottish Government Web Page. Marine Energy. Available online: http://www.scotland.gov.uk/ Topics/marine/marineenergy (accessed on 9 June 2013).

28. Tyndall Centre Web Page. Tidal Stream Energy in the UK: Stakeholder Perceptions Study. Available online: http:/www.tyndall.ac.uk/publications/working-paper/2010/tidal-stream-energyuk-stakeholder-perceptions-study (accessed on 10 June 2013).

29. Ernst \& Young. Cost of and Financial Support for Wave, Tidal Stream and Tidal Range Generation in the UK; A Report for the Department of Energy and Climate Change and the Scottish Government; Ernst \& Young: London, UK, 2010.

30. Kreab \& Gavin Anderson. Wave \& Tidal-Investor Survey; Department of Energy \& Climate Change: London, UK, 2010. Available online: http://webarchive.nationalarchives.gov.uk/ 20121205174605/http:/decc.gov.uk/assets/decc/what\%20we\%20do/uk\%20energy\%20supply/ energy $\% 20 \mathrm{mix} /$ renewable\%20energy/explained/wave_tidal/799-decc-wave-and-tidal--investorsurvey.pdf (accessed on 9 June 2013).

31. IBTimes Company Web Page. Renewable Energy Markets still Feeling Effects of Recession. Available online: http://www.ibtimes.co.uk/articles/20110302/renewable-energy-markets-039still-feeling-effects-recession-039.htm (accessed on 9 June 2013).

32. Community Research and Development Information Service Web Page. Funding. Available online: http://cordis.europa.eu/fp7/home_en.html (accessed on 9 June 2013).

33. GOV.UK Web Page. 220 Million Marine Scheme Now Open. Available online: https://www.gov.uk/ government/news/20million-marine-scheme-now-open (accessed on 9 June 2013). 
34. Carbon Trust Web Page. Marine Renewables Proving Fund. Available online: http://www.carbontrust.com/client-services/technology/innovation/marine-renewables-proving-fund (accessed on 9 June 2013).

35. Carbon Trust Web Page. Marine Renewables Commercialisation Fund. Available online: http://www.carbontrust.com/client-services/technology/innovation/marine-renewablescommercialisation-fund (accessed on 9 June 2013).

36. Energy Technologies Institute Web Page. Marine-Strategic Context. Available online: http://www.eti.co.uk/technology_programmes/marine (accessed on 9 June 2013).

37. Energy Technologies Institute Web Page. ETI Announces Tidal Energy Converter (TEC) System Demonstrator Project; News. Available online: http://www.eti.co.uk/news/article/eti_announces_ tidal_energy_converter_tec_system_demonstrator_project (accessed on 28 June 2013).

38. Technology Strategy Board Web Page. Funding Competitions. Available online: https://www.innovateuk.org/funding-competitions?p_p_id=tsbcompetitionsearchportlet_WAR_ tsbcompetitionsearchportlet\&p_p_lifecycle $=0 \& p \_p \_s t a t e=$ normal $\& p \_p \_$mode $=$view $\& p \_p \_c o l \_i d=$ column1\&p_p_col_count $=2 \&$ tsbcompetitionsearchportlet_WAR_tsbcompetitionsearchportlet_ta bName $=$ closed (accessed on 9 June 2013).

39. Parliament.co.uk Web Page. HC 1624 Energy and Climate Change Committee; Memorandum Submitted by the Technology Strategy Board. Available online: http://www.publications.parliament.uk/pa/cm201012/cmselect/cmenergy/1624/1624we09.htm (accessed on 28 June 2013).

40. Scottish Government Web Page. What is the Scottish Ministers' Wave and Tidal Energy Support Scheme? Available online: http://www.scotland.gov.uk/Topics/Business-Industry/Energy/Energysources/19185/20805/WTSupportScheme/WTSupportSchemeIntro (accessed on 9 June 2013).

41. Saltire Prize Web Page. The Challenge. Available online: http://www.saltireprize.com/challenge (accessed on 9 June 2013).

42. Northern Ireland Environment Link. Consultation on an Offshore Renewable Energy Strategic Action Plan 2009-2020; Habitats Regulations Assessment-Screening Report and Appropriate Assessment; Northern Ireland Environment Link: Belfast, Ireland, 2010.

43. Department of Energy \& Climate Change Web Page. Increasing the Use of Low-Carbon Technologies; The Renewables Obligation. Available online: https:/www.gov.uk/government/ policies/increasing-the-use-of-low-carbon-technologies/supporting-pages/the-renewables-obligation-ro (accessed on 10 June 2013).

44. Henriques, I.; Sadorsky, P. Oil prices and the stock prices of alternative energy companies. Energy Econ. 2008, 30, 998-1010.

45. MIT Web Page. A Shale Gas Revolution? Available online: http://web.mit.edu/ newsoffice/2012/shale-gas-revolution-report.html (accessed on 10 June 2013).

46. National Geographic Web Page. Shale Gas: A Boon that Could Stunt Alternatives, Study Says. Available online: http://news.nationalgeographic.co.uk/news/energy/2012/01/120117-shale-gasboom-impact-on-renewables/ (accessed on 10 June 2013).

47. European Ocean Energy Web Page. Industry Vision Paper. Available online: http://www.oceanenergy-europe.eu/index.php/communication/what-s-new/75-industrial-visionpaper-launched-at-the-european-parliament (accessed on 10 June 2013). 
48. National Renewable Energy Laboratory. Dollars from Sense. The Economic Benefits of Renewable Energy; National Renewable Energy Laboratory: Golden, CO, USA, 1997. Available online: http://www.nrel.gov/docs/legosti/fy97/20505.pdf (accessed on 10 June 2013).

49. RenewableUK Web Page. Best Practise Guide to Wave and Tidal Power Insurance; A Paper by JLT Specialty Limited on Behalf of RenewableUK's Marine Strategy Group. Available online: http://www.renewableuk.com/en/publications/reports.cfm/wt-insurance (accessed on 10 June 2013).

50. Vivid Economics. The Green Investment Bank: Policy and Finance Context; Report Prepared for the Department for Business Innovation and Skills; Vivid Economics: London, UK, 2011. Available online: https:/www.gov.uk/government/uploads/system/uploads/attachment_data/file/ 31757/12-553-green-investment-bank-policy-and-finance-context.pdf (accessed on 30 June 2013).

51. Green Investment Bank Web Page. Our Mission, Mandate Purpose and Strategy. Available online: http://www.greeninvestmentbank.com/what-we-do/our-investment-approach.html (accessed on 30 June 2013).

52. Cornerstone Barristers Web Page. Cornerstone Team Begin Powys Wind Farm Inquiry. Available online: http://cornerstonebarristers.com/news/cornerstone-team-begin-powys-windfarm-inquiry/ (accessed on 10 June 2013).

53. Wind Farm Inquiry Costs. Available online: http://www.powys.gov.uk/index.php?id= $14550 \& \mathrm{~L}=0$ (accessed on 10 June 2013).

54. West, J.; Bailey, I.; Winter, M. Renewable energy policy and public perceptions of renewable energy: A cultural theory approach. Energy Policy 2010, 38, 5739-5748.

55. Sorensen, H.C.; Hansen, L.K.; Hansen, R.; Hammarlund, K. E Social, Planning and Environmental Impact. Available online: http://mhk.pnnl.gov/wiki/images/d/d0/Social, Planning_and_Environmental_Impact.pdf(accessed on 10 June 2013).

56. Devine-Wright, P. Place attachment and public acceptance of renewable energy: A tidal energy case study. J. Environ. Psychol. 2011, 31, 336-343.

57. Sustainable Development Commission Web Page. Engagement Report-Public and Stakeholder Engagement Programme; A Report by the Opinion Leader and The Environment Council for the Sustainable Development Commission. Available online: http://www.sd-commission.org.uk/ publications.php?id=612 (accessed on 10 June 2013).

58. Pidgeion, N.F.; Lorenzoni, I.; Poortinga, W. Climate change or nuclear power-No thanks! A quantitative study of public perceptions and risk framing in Britain. Glob. Environ. Chang. 2008, 18, 69-85.

59. Batel, S.; Devine-Wright, P.; Tangeland, T. Social acceptance of low carbon energy and associated infrastructures: A critical discussion. Energy Policy 2013, 58, 1-5.

60. Howell, A.; Drake, C. Scoping Study on Socio-Economic Impacts of Tidal Energy Development in Nova Scotia: A Research Synthesis \& Priorities for Future Action. Fundy Energy Research Network: Wolfville, Canada, 2012. Available online: http://www.marinerenewables.ca/wp-content/ uploads/2012/11/Scoping-Study-on-Socio-Economic-Impacts-of-Tidal-Energy-Developmentin-Nova-Scotia-A-Research-Synthesis-Priorities-for-Future-Action.pdf (accessed on 10 June 2013).

61. Devine-Wright, P. Enhancing local distinctiveness fosters public acceptance of tidal energy: A UK case study. Energy Policy 2011, 39, 83-93. 
62. Mackinson, S.; Curtis, H.; Brownm, R.; McTaggart, K.; Taylor, N.; Neville, S.; Rogers, S. A Report on to the Perceptions of the Fishing into the Potential Socio-Economic Impacts of Offshore Wind Energy Developments on Their Work Patterns and Income; Centre for Environment, Fisheries \& Aquaculture Science: Lowestoft, UK, 2006. Available online: http://www.cefas.defra.gov.uk/publications/techrep/tech133.pdf (accessed on 10 June 2013).

63. Maritime and Coastguard Agency. Offshore Renewable Energy Installations (OREIs): Guidance to Mariners Operating in the Vicinity of UK OREIs; Maritime and Coastguard Agency: Southampton, UK, 2008. Available online: http://www.dft.gov.uk/mca/mgn372.pdf (accessed on 10 June 2013).

64. Royal Yacht Association. The RYA's Position on Offshore Renewable Energy Developments: Paper 3 (of 3)_Tidal Energy; Royal Yacht Association: Southampton, UK, 2012. Available online: http://www.rya.org.uk/SiteCollectionDocuments/legal/Web\%20Documents/Environment/RYA\% 20Position\%20OREI\%20Tidal\%20-\%20March\%202012.pdf (accessed on 10 June 2013).

65. Maritime and Coastguard Agency Web Page. Offshore Renewable Energy Installations: Impact on Shipping. Available online: https://www.gov.uk/offshore-renewable-energyinstallations-impact-on-shipping (accessed on 10 June 2013).

66. Wyre Tidal Energy Web Page. Tidal Benefits. Available online: http://www.wyretidalenergy.com/ tidal-benefits (accessed on 10 June 2013).

67. ICE Web Page. Offshore Renewables: Unlocking the Potential. Available online: http://www.ice.org.uk/Information-resources/Document-Library/Offshore-renewables--unlockingthe-potential (accessed on 11 June 2013).

68. Scottish Enterprise Web Page. Offshore Renewable Supply Chain Directory; Energy. Available online: http://www.scottish-enterprise.com/your-sector/energy/offshore-wind/companysearch.aspx (accessed on 16 June 2013).

69. Easton, S.; Hayman, J.; Stoddart-Scott, D.; Hewitt, A. Techno-Economic Analysis of Tidal Turbine Installation and Access; Sustainable Marine Technologies: London, UK, 2011. Available online: http://www.see.ed.ac.uk/ shs/EWTEC\%202011\%20full/papers/265.pdf (accessed on 16 June 2013).

70. McMillan, D.; Ault, G.W. Specification of Reliability for Offshore Wind Farms. University of Strathclyde: Glasgow, UK. Available online: http://www.maths.stir.ac.uk/ kjt/research/prosen/ pub/esrel08-mcmillan.pdf (accessed on 16 June 2013).

71. Energy Efficiency and Renewable Energy Web Page. Tidal Energy. Available online: http://www.eere.energy.gov/basics/renewable_energy/tidal_energy.html (accessed on 16 June 2013).

72. European Marine Energy Centre Web Page. Tidal Devices. Available online: http://www.emec.org.uk/marine-energy/tidal-devices/ (accessed on 11 June 2013).

73. McAlister, C. Review and Analysis of Ocean Energy Systems Development and Supporting Policies; A report by AEA Energy \& Environment on behalf of Sustainable Energy Ireland for the IEA's Implementing Agreement on Ocean Energy Systems; AEA Energy \& Environment: Oxford, UK, 2006. 
74. Seibert, M.G. Determining Anchoring Systems for Marine Renewable Energy Devices Moored in a Western Boundary Current. Master's Thesis, Florida Atlantic University, Boca Raton, FL, USA, 2011. Available online: http://snmrec.fau.edu/sites/default/files/research/theses/DT-11-122.pdf (accessed on 16 June 2013).

75. Starling, M.; Scott, A. Foundations and Moorings for Tidal Stream Systems; Produced on behalf of The Carbon Trust; BMT Cordah: London, UK, 2009. Available online: $\mathrm{http}: / / \mathrm{www}$. carbontrust.com/media/170419/foundations-and-moorings-tidal-systems.pdf (accessed on 16 June 2013).

76. Atlantis Resource Corporation Web Page. Tidal Current Power. Available online: $\mathrm{http} / /$ www.atlantisresourcescorporation.com/marine-power/tidal-current-power.html (accessed on 16 June 2013).

77. Thake, J. Development, Installation and Testing of a Large Scale Tidal Current Turbine; Department of Trade and Industry: London, UK, 2005. Available online: http://www.berr.gov.uk/files/file18130.pdf (accessed on 11 June 2013).

78. TidalStream Web Page. Resource. Stream Depth Effects. Available online: http://www.tidalstream.co.uk/html/resource.html (accessed on 11 June 2013).

79. Det Norske Veritas. Guidelines on Design and Operation of Wave Energy Converters; A guide to assessment and application of engineering standards and recommended practices for wave energy conversion devices; Carbon Trust: London, UK, 2005. Available online: www.dnvkema.com/Images/WECguideline_tcm4-270406.pdf (accessed on 11 June 2013).

80. National Renewable Energy Laboratory Web Page. Computer Aided Engineering; Water Power Research. Available online: http://www.nrel.gov/water/engineering.html (accessed on 16 June 2013).

81. Neuhoff, K. Large Scale Deployment of Renewables for Electricity Generation; Cambridge Working Papers in Economics CWPE 0460. Available online: http://www.dspace.cam.ac.uk/handle/1810/131566 (accessed on 16 June 2013).

82. Carbon Trust Web Page. Accelerating Marine Energy; What Were the Aims of the Marine Energy Accelerator? Available online: http://www.carbontrust.com/resources/reports/technology/ accelerating-marine-energy (accessed on 7 June 2013).

83. European Marine Energy Centre Web Page. Standards. Available online: http://www.emec.org.uk/standards/ (accessed on 16 June 2013).

84. The Crown Estates. Subsea Cables and Offshore Renewable Energy Installations; Proximity Study; The Crown Estates: London, UK, 2012. Available online: http:/www.thecrownestate.co.uk/ media/313713/submarine_cables_and_offshore_renewable_energy_installations_proximity_study.pdf (accessed on 16 June 2013).

85. OffshoreGrid. Offshore Electricity Grid Infrastructure in Europe; A techno-Economic Assessment; OffshoreGrid: Brussels, Belgium, 2011. Available online: http://www.ewea.org/ fileadmin/ewea_documents/documents/publications/reports/OffshoreGrid_report.pdf (accessed on 16 June 2013).

86. Climate Change Capital. Offshore Renewable Energy Installation Decommissioning Study; Final Report; Climate Change Capital: London, UK, 2011. Available online: https://www.gov.uk/ government/uploads/system/uploads/attachment_data/file/47955/900-offshore-renewable-installationdecom.pdf (accessed on 16 June 2013). 
87. National Renewable Energy Laboratory Web Page. Ocean Energy Results-Life Cycle Assessments. Energy Analysis. Available online: http://www.nrel.gov/analysis/sustain lca_ocean.html (accessed on 16 June 2013).

88. GOV.UK Web Page. Simplifying Marine Regulations; Protecting and Sustainably Using the Marine Environment. Available online: https:/www.gov.uk/government/policies/protecting-andsustainably-using-the-marine-environment (accessed on 16 June 2013).

89. United Nations Web Page. United Nations Convention on the Law of the Sea of 10 December 1982; Overview and Full Text. Available online: http://www.un.org/depts/los/ convention_agreements/convention_overview_convention.htm (accessed on 16 June 2013).

90. EUR-Lex Web Page. Directive 2009/28/EC of the European Parliament and of the Council of 23 April 2009 on the Promotion of the Use of Energy from Renewable Sources and Amending and Subsequently Repealing Directives 2001/77/EC and 2003/30/EC. Available online: http://eur-lex.europa.eu/LexUriServ/LexUriServ.do?uri=CELEX:32009L0028:EN:NOT (accessed on 30 June 2013).

91. European Commission Web Page. Renewable Energy: Commission Refers Poland and Cyprus to Court for Failing Transpose EU Rules. Available online: http://europa.eu/rapid/press-release_IP13-259_en.htm (accessed on 30 June 2013).

92. European Commission Web Page. Environmental Assessment. Available online: http://ec.europa.eu/ environment/eia/ (accessed on 15 June 2013).

93. European Commission Web Page. The Habitats Directive. Available online: http://ec.europa.eu/ environment/nature/legislation/habitatsdirective/ (accessed on 16 June 2013).

94. European Commission Web Page. The Birds Directive. Available online: http://ec.europa.eu/ environment/nature/legislation/birdsdirective/ (accessed on 16 June 2013).

95. European Commission Web Page. The EU Framework Directive-Integrated River Basin Management for Europe. Available online: http://ec.europa.eu/environment/water/ water-framework/ (accessed on 16 June 2013).

96. European Commission Web Page. A Marine Strategy Directive to Save Europe's Seas and Oceans. Available online: http://ec.europa.eu/environment/water/marine/directive_en.htm (accessed on 16 June 2013).

97. European Commission Web Page. Marine Spatial Planning: Why does the EU Need Rules for Maritime Spatial Planning? Available online: http://ec.europa.eu/maritimeaffairs/policy/ maritime_spatial_planning/index_en.htm (accessed on 16 June 2013).

98. Jeffrey, H.; Sedgwick, J. European Offshore Renewable Energy Roadmap; ORECCA Coordinated Action Project: European Union, 2011. Available online: http://www.orecca.eu/c/ document_library/get_file?uuid=1e696618-9425-4265-aaff-b15d72100862\&groupId=10129 (accessed on 16 June 2013).

99. GOV.UK Web Page. Consents and Planning Applications for National Energy Infrastructure Projects; Guidance on Regulations Covering New Power Generating Plants and Wayleaves. Available online: https://www.gov.uk/consents-and-planning-applications-for-national-energyinfrastructure-projects (accessed on 16 June 2013). 
100. Department of Energy \& Climate Change. National Policy Statement for Renewable Energy Infrastructure (EN-3); Department of Energy \& Climate Change: London, UK, 2011. Available online: https:/whitehall-admin.production.alphagov.co.uk/government/uploads/system/uploads/ attachment_data/file/37048/1940-nps-renewable-energy-en3.pdf (accessed on 16 June 2013).

101. Marine Management Organisation Web Page. Marine Licensing; What a Marine License is for. Available online: http:/www.marinemanagement.org.uk/licensing/marine.htm (accessed on 16 June 2013).

102. Natural Resources Wales Web Page. Marine Licensing. Available online: http://naturalresourceswales.gov.uk/apply-buy-report/apply-buy-grid/marine-licensing/?lang=en\#. Ub37ZPkqjbk (accessed on 16 June 2013).

103. Department of the Environment (Northern Ireland) Web Page. Marine Licensing Northern Ireland. Available online: http://www.doeni.gov.uk/niea/water-home/marine_licensing_ni-3.htm (accessed on 16 June 2013).

104. Scottish Government Web Page. Marine Licensing in Scotland. Available online: http://www.scotland.gov.uk/Topics/marine/Licensing/marine (accessed on 16 June 2013).

105. Energy Infrastructure Web Page. Recent Decisions on Applications; A DECC service for England and Wales. Available online: https://www.og.decc.gov.uk/EIP/pages/recent.htm (accessed on 16 June 2013).

106. GOV. UK Web Page. Decommissioning Offshore Renewable Energy Installations. Available online: https://www.gov.uk/government/publications/decommissioning-offshore-renewableenergy-installations (accessed on 16 June 2013).

107. The Crown Estates Web Page. 36 Wave and Tidal Sites as New Projects Announced. Available online: http://www.thecrownestate.co.uk/news-media/news/2012/uk-wave-and-tidal-sites-total36-as-three-new-projects-announced/ (accessed on 16 June 2013).

108. British Wind Energy Association. Guidelines for Health and Safety in the Marine Energy Industry; British Wind Energy Association: London, UK, 2008. Available online: http://www.emec.org.uk/download/5\%20Guidelines\%20for\%20Health\%20and\%20Safety\%20in \%20the\%20Marine\%20Energy\%20Industry.pdf (accessed on 16 June 2013).

109. RenewableUK Web Page. Offshore Wind and Marine Energy Health and Safety Guidelines; Issue 1. Available online: http:/www.renewableuk.com/en/our-work/health-and-safety/ (accessed on 16 June 2013).

110. Intellectual Property Office Web Page. Apply for a Patent. Available online: http://www.ipo.gov.uk/p-apply.htm (accessed on 16 June 2013).

111. Natural England Web Page. Renewable Energy; Benefits and consequences of Renewable Sources. Available online: http://www.naturalengland.org.uk/ourwork/climateandenergy/energy/ renewable/default.aspx (accessed on 15 June 2013).

112. Frid, C.; Andonegi, E.; Depestele, J.; Judd, A.; Rihan, D.; Rogers, S.I.; Kenchington, E. The environmental interactions of tidal and wave energy generation devices. Environ. Impact Assess. Rev. 2011, 32, 133-139.

113. Marine Current Turbines. SeaGen Environmental Monitoring Programme; Final Report; Royal Haskoning: Edinburgh, UK, 2011. Available online: http://www.marineturbines.com/sites/default/ files/SeaGen-Environmental-Monitoring-Programme-Final-Report.pdf (accessed on 15 June 2013). 
114. Leon, J. Fundy Tidal Energy Strategic Environmental Assessment Final Report; Offshore Energy Research Association (OEER): Nova Scotia, Canada, 2008. Available online: http://www.oera.ca/wp-content/uploads/2013/06/FINAL-SEA-REPORT.pdf (accessed on 27 September 2013).

115. El-Geziry, T.M.; Bryden, I.G.; Couch, S.J. Environmental Impact Assessment for Tidal Energy Schemes: An Exemplar Case Study of the Strait of Messina. The University of Edinburgh. Available online: http://www.research.ed.ac.uk/portal/en/publications/environmental-impact-assessment-fortidal-energy-schemes-an-exemplar-case-study-of-the-strait-of-messina(aa7c23ef-8db3-406d-a2f01646469fe35b)/export.html (accessed on 15 June 2013).

116. GOV.UK Web Page. What We Do; Inside Government. Available online: https://www.gov.uk/government/organisations/department-for-environment-food-rural-affairs (accessed on 15 June 2013).

117. Joint Nature Conservation Committee Web Page. Offshore Renewable Energy. Available online: http://jncc.defra.gov.uk/page-4274 (accessed on 15 June 2013).

118. Cefas Web Page. Guidelines for Data Acquisition to Support Marine Environmental Assessments of Offshore Renewable Energy Projects. Available online: http://www.cefas.defra.gov.uk/ our-science/assessing-human-impacts/offshore-renewable-energy.aspx (accessed on 15 June 2013).

119. Marine Management Organisation Web Page. Wildlife Licenses; Protecting the Environment. Available online: http://www.marinemanagement.org.uk/protecting/wildlife/index.htm (accessed on 15 June 2013).

120. World Wide Fund for Nature. Marine Renewable Energy for the UK; Policy Position; Morges, Switzerland, 2005. Available online: www.wwf.org.uk/filelibrary/pdf/marine_renewable_ energy.pdf (accessed on 15 June 2013).

121. McCluskie, A.E.; Langston, R.H.W.; Wilkinson, N.I. Birds and Wave \& Tidal Stream Energy: an Ecological Review; RSPB Research Report No. 42; The Royal Society for the Protection of Birds: Sandy, UK, 2012. Available online: http://www.rspb.org.uk/Images/ mccluskie_langston_wilkinson_2012_tcm9-307966.pdf (accessed on 15 June 2013).

122. Marine Board. Marine Renewable Energy. Research Challenges and Opportunities for a New Energy Era in Europe; Marine Board: Ostend, Belgium, 2010. Available online: http://www.esf.org/fileadmin/Public_documents/Publications/MB_vision_document2.pdf (accessed on 15 June 2013).

123. Equimar Web Page. Uncertainties Regarding Environmental Impacts-A Draft; Equitable Testing and Evaluation of Marine Energy Extraction Devices in Terms of Performance, Cost and Environmental Impact. Available online: http://www.equimar.org/equimar-projectdeliverables.html (accessed on 15 June 2013).

124. Association of Salmon Fishery Boards. Comments on SEA Screening and Scoping Report for the Sectoral Marine Plan for Wave and Tidal Energy in Scotland's Renewable Energy Zone; Association of Salmon Fishery Boards: Edinburgh, UK, 2011. Available online: http://www.asfb.org.uk/wp-content/uploads/2011/04/ASFB-RAFTS-response-SEA-SS-WaveTidal-Sep-2011.pdf (accessed on 15 June 2013). 
125. The Welsh Government Web Page. Collision Risk of Fish with Wave and Tidal Energy Devices; Commissioned by RPS Group PLC on Behalf of the Welsh Assembly Government. Available online: http://wales.gov.uk/topics/environmentcountryside/energy/renewable/marine/framework/? lang=en (accessed on 15 June 2013).

126. A Scoping Study for an Environmental Impact Field Programme in Tidal Current Energy; The Robert Gordon University: Aberdeen, UK, 2002. Available online: http://www.dti.gov.uk/ renewables/publications/pdfs/t0400213.pdf (accessed on 15 June 2013).

127. Boehlert, G.W.; Gill, A.B. Environmental and Ecological Effects of Ocean Renewable Energy Developments. Available online: http://www.engpaper.com/environmental-and-ecological-effects-ofocean-renewable-energy-development-current-synthesis.htm (accessed on 15 June 2013).

128. Linley, A.; Laffont, K.; Wilson, B.; Elliott, M.; Perez-Dominguez, R.; Burdon, D. Offshore and Coastal Renewable Energy: Potential Ecological Benefits and Impacts of Large-Scale Offshore and Coastal Renewable Energy Projects; Northeast Recycling Council: Brattleboro, VT, USA, 2009. Available online: http://www.nerc.ac.uk/research/programmes/mre/documents/marinescoping-study-1.pdf (accessed on 15 June 2013).

129. Inger, R.; Attrill, M.J.; Bearshop, S.; Broderick, A.C.; Grecian, W.J.; Hodgson, D.J.; Mills, C.; Sheehan, E.; Votier, S.C.; Witt, M.J.; et al. Marine renewable energy: Potential benefits to biodiversity? An urgent call for research. J. Appl. Ecol. 2009, 46, 1145-1153.

(C) 2013 by the authors; licensee MDPI, Basel, Switzerland. This article is an open access article distributed under the terms and conditions of the Creative Commons Attribution license (http://creativecommons.org/licenses/by/3.0/). 